\title{
Structuring Workers' Bargaining Power in Mexico's Strawberry Fields
}

\author{
Matthew Fischer-Daly, Cornell University, USA
}

\begin{abstract}
Workers shut down production and transportation of strawberries during the peak of the 2015 harvest in San Quintín, Mexico, which supplies winter berries to US markets. In the years since the strike, strike-settlement wage increases have eroded, commitments to register workers in the national social security system fell far short, and no workers gained representation by a union in collective bargaining with their employer. This case analyses the limited strike outcomes and persistent gaps in labour law compliance based on interviews and observation in 2019 and 2020. Building on the power resources approach, it highlights the historical character of structural power. Falling short of achieving strike demands underscored constraints on workers' disruptive capacity. The case suggests that reading structural power as a dynamic complex of actions by employers, national states and workers enhances the concept's ability to predict effects of collective action on social relations of production.
\end{abstract}

\section{KEYWORDS}

Mexico; agriculture; supply chains; bargaining power; structural power

\section{Introduction}

Tens of thousands of workers struck and shut down transportation during the peak strawberry harvest in San Quintín, Baja California, Mexico, on 17 March 2015. Over the three decades leading up to the strike, strawberries were transformed from a local seasonal specialty into an internationally traded commodity sold year-round. From zero exports in 1988, Mexico is now the second-largest strawberry exporter worldwide, accounting for 90 per cent of United States (US) strawberry imports (UN Comtrade), mostly sold by retailers led by Walmart. At the time of their mass strike, workers needed six minimum wages to cover basic needs, women suffered sexual violence at work, wage rates had stagnated for decades, and most workers were unregistered in the national social security system, the Instituto Mexicano del Seguro Social (IMSS), which provides essential health care and social services (Zlolniski, 2010: 168; CAM, 2015; INEGI, 2016). Strikers disrupted berry supplies for US retail sales prior to the production season in their northern neighbour. Led by the Alliance of National, State, and Municipal Organizations for Social Justice, they demanded compliance with national laws, particularly freedom of association and collective bargaining rights, registration in IMSS to access health care and pensions, cessation of genderbased violence at work and living wages. ${ }^{1}$ The federal government registered the Independent

\footnotetext{
1 The "March 17 Manifesto" demands, on file with the author, include the following: 1. revocation of protection contracts; 2. payment of pensions reflecting full tenure; 3. registration in the Mexican Institute
} 
National Democratic Union of Agricultural Day Labourers (Sindicato Independiente Nacional Democrático de Jornaleros Agrícolas, SINDJA), and employers increased wages and IMSS registrations. However, five years after the strike, employer-protection unions continued to block collective bargaining, inflation and work intensification had eroded strike-settlement wage increases, most workers remained unregistered in IMSS and gender-based discrimination remained pervasive.

The growth of strawberry production in San Quintín and persistence of super-exploitative employment terms and conditions despite the mass strike highlight the historical construction of structural power through strategic use of economic, political and social forces. In the power resources literature, structural power tends to be treated as given by capitalism's "laws", as opposed to conditions reflecting the actions of capitalists, national states and workers in a particular place and time. As the necessary labour for the two-month peak harvest which US food retailers depend on for winter berry sales, the San Quintín workers are "enmeshed in tightly integrated production processes, where a localized work stoppage in a key node can cause disruptions on a much wider scale than the stoppage itself', as Beverly Silver (2003: 13) described workplace structural power. While not a railway stoppage, the strike threatened retailers' highest revenue category in produce (Cook, 2011). This article argues that workers did not achieve most of their strike demands due to the interactive effects of the organised commodity network ${ }^{2}$ that insulates capital from them, a racialised division of labour and national state selectivity in law enforcement. Reading structural power's dynamism explicates the case, and points to the changes required to alter workers' position in society.

This article results from fieldwork conducted in 2019 and 2020. A two-month visit to San Quintín provided most primary data. Guided by protocols and questionnaires reviewed and exempted for human participant studies by the Institutional Review Board, sixty-seven semistructured interviews were conducted: forty-one workers, six unionist-workers, five managers, three state officials, seven activists and six academics. On average, 86 per cent of workers identified as indigenous, 56 per cent male and 44 per cent female. Managers were all men with European heritage. To interview workers, community leaders were contacted via WhatsApp, then snowballing technique was used to expand perspectives beyond recommended persons. Thirty companies were contacted. Five managers were interviewed - four at independent production agribusinesses in the San Quintín Valley and one at Driscoll's, the world's largest berry brand. Officials at Mexico's Secretariat for Labor and Social Welfare (Secretaría del Trabajo y Previsión Social, STPS) and IMSS participated. A day harvesting strawberries and two months spent observing strawberry agribusinesses and workers' organisations provided supplementary information. Secondary sources guided fieldwork, which covered demographics, migration, the

of Social Security; 4. six-day work week and paid leave on the seventh day, holidays and vacation; 5. payment of overtime wage rates; 6 . maternity leave of six weeks prior to and six weeks after births 7 . paid paternity leave; 8. end of and zero tolerance for sexual assaults by managerial staff; 9. no retaliation against strikers; 10. daily payrate of 300 pesos, an increase from then prevailing rate of 120 pesos per day; 11 . payrate of 30 pesos per box of strawberries, and double rates on Sundays and holidays; 12. payrate of 17 pesos per bucket of blackberries; 13 . payrate of 8 pesos per bucket of tomatoes; 14 . just payment and good social coexistence between employers and workers.

2 The terms "commodity network" and "international commodity network" are used in this article to refer to the processes of production, circulation and consumption of commodities. The terminology departs from "global value chains" and similar phrases in order to emphasise the central role of national states in international commercial trade, that things with use and exchange values are the objects of this trade, and that the actors involved in it are embedded in socio-political and economic networks. 
labour process and living conditions, as well as relations between workers, employers and government actors. Quotes and other information presented are from interviews unless otherwise cited. Open coding of interviews identified patterns (Corbin and Strauss, 1990), which were juxtaposed with extant understandings of structural and associational power, following a historicalsociological approach (Bonnell, 1980).

\section{Towards a Historical Understanding of Structural Power}

"[A] deficiency of classical political economy is the fact that it does not conceive the basic form of capital, i.e., production designed to appropriate other people's labour, as a historical form but as a natural form of social production" (Marx, 1989 [1863]: 47). While often recognising the dynamism of class relations in principle, studies of bargaining power repeat the tendency to treat structural power as transcendent. The common definition of structural power is "power that results simply from the location of workers within the economic system" (Wright, 2000: 962). It is considered "an important constant or embedded condition within a given industry or labour market at a point in time (Doellgast, Lillie and Pulignano, 2018: 14) that "shapes the social field of action so as to render some kinds of behaviour possible, while making others less possible or impossible" (Wolf, 1990: 587).

Structural power is also understood as "disruptive power", the capacity "to interrupt or restrict the valorization of capital" (Piven, 2008: Ch. 2). The strength of labour's structural power depends on "strategic locations in production processes" (Rhomberg and Lopez, 2021: 47), or workers' capacity to disrupt capital accumulation processes of their direct employer and of companies linked to it through exchange relations. Its potency also depends on workers' ability to sustain the disruption, or strike leverage (Katz, Kochan and Colvin, 2017), significantly determined by the tightness or looseness of the labour market (Wright, 2000; Silver, 2003). Thus, structural power of workers is higher when capitalists cannot easily replace workers with spatial or technical fixes (such as robots or subcontracting) (Harvey, 1999; Reinecke and Donaghey, 2015; Wood, 2015), are sensitive to delays (for example, just-in-time business models) (Silver, 2003), and face stronger market-share competition (Pulignano and Signoretti, 2016).

Towards an analysis beyond "how power is used" to "what power is used for" (Gallas, 2018: 349), labour studies are challenged to attend to the "political economy and relations of property, market relations, political power and the state" and how worker collective action impacts them (Nowak, 2018: 357). On the level of analysis, if studying commodity circuits enhances understanding of power in the international political economy (Hopkins and Wallerstein, 1977), then it must address how social actors use economic, political and social forces (Dicken et al., 2001). Such provocations suggest reading power as the structuring of commodity circuits and the class relations that underpin them. Understanding structural power as historically formed and thus a contestable set of conditions may expand the horizon of workers' path to change.

\section{Structuring Bargaining Power to Re/Create Strawberry Production in San Quintín}

The use of economic, political and social forces to construct the strawberry sector in San Quintín and limit labour's gains through the 2015 mass strike illustrates the dynamism of structural power. The international network of companies in the strawberry sector insulates capital from situations 
where labour has the capacity to disrupt surplus accumulation processes and separates workers across production, transportation and sales, and across political borders. Use of the social hierarchies of racialism and patriarchy intersect with neo-liberal development policies to organise a surplus and differentiated labour market. Exemptions and selective enforcement of laws strengthen managerial discretion while suppressing labour collective action.

Understanding bargaining power as the capacities of management and labour to advance their interests despite resistance, analysis begins with identifying the forms of resistance. Capital expansion confronts resistance from nature's control of agriculture. Absolute surplus capital accumulation is constrained by the limits of the quantity of labour that can be applied without detrimentally affecting products (Mann and Dickinson, 1979; Mann, 1990). Increasing the profit rate is limited by seasonality, which stagnates capital between planting and harvesting and slows returns on investments in productivity enhancements. Weather and lifeforms such as insects and bacteria limit predictability of yields. Spatial fixes, moving capital away from disruptions of accumulation processes, are also limited by plants' needs for particular climatological and ecological conditions and perishability's imposition of requirements for fast transport to markets.

Thus, the strawberry sector has grown in part by pushing natural limits. Expansion of production to Mexico increased profits in absolute terms, with more land and labour in production and winter supplies for retailers to complement summertime supplies from US production to enable year-round sales. Mexico's production growth averaged 14 per cent compared to 0.3 per cent in the United States during the 2010s (FAO, Undated b). It accounts for 90 per cent of strawberry imports to the United States (UN Comtrade), where sales of strawberries have doubled since the late 1990s (Shelman, 2017), and berries became the highest revenue category in retail produce (Cook, 2011). Applications of fumigants, pesticides, fungicides and fertilisers seek to stabilise production. ${ }^{3}$ Spatially, locating production in San Quintín capitalises on its temperate, ocean-modulated climate and sandy soils, ideal for strawberries, and on its proximity to US markets, 186 miles to the north.

While struggling against nature is part of the formula, "control over labour [is] the central determinant of profitability" in the strawberry sector (Wells, 1996: 44). Labour accounts for an estimated 60 per cent of strawberry production costs and 70 per cent of food retail costs (Lichtenstein, 2008). ${ }^{4}$ As capitalists began investing in San Quintín following the Mexican government's construction of the trans-peninsular highway and shifts in subsidies from peasant to export food production, they encountered lands depopulated by prior colonialists who had decimated indigenous Kiliwa and Cohomi residents (Zlolniski, 2019). Whereas the wage differential - harvesters earned approximately $\$ 18$ to $\$ 28$ per day in San Quintín compared to $\$ 14$ to $\$ 18$ per hour in the United States in 2020 - means higher margins for leading buyers, such as Driscoll's and Walmart, for production companies they incentivise labour emigration, more so prior to stricter border enforcement. ${ }^{5}$ Labour control has been tenuously achieved through the network

\footnotetext{
${ }^{3}$ According to managers and workers interviewed, Telone ${ }^{\circledR}$ or similar commercial products based on chloropicrin, also an active ingredient used for tear gas, is a common fumigant; Bifenthrin, a suspected carcinogen, is a common pesticide; and Carbendazim, an endocrine and reproductive system disruptor, is a common fungicide (FAO, Undated a; EWG, 2019).

${ }^{4}$ University of California Cooperative Extension researchers estimated that labour costs accounted for 60 per cent of total costs for strawberry production companies in the state's Central Coast Region (Tourte, Bolda and Klonsky, 2016). While their data is from a location other than those studied here, it is consistent with descriptions shared by production managers interviewed in San Quintín.
}

${ }^{5}$ Wage rates in San Quintín are based on interviews with managers and workers. For US rates, the 2020 
organisation of capital, organisation of a surplus and differentiated labour market, and selective enforcement of laws in the strawberry sector. As shown in Figure 1, these strategic actions structure bargaining power and explain the 2015 strike outcomes.

Social hierarchies (differentiate \& divide workers, externalize labor costs)

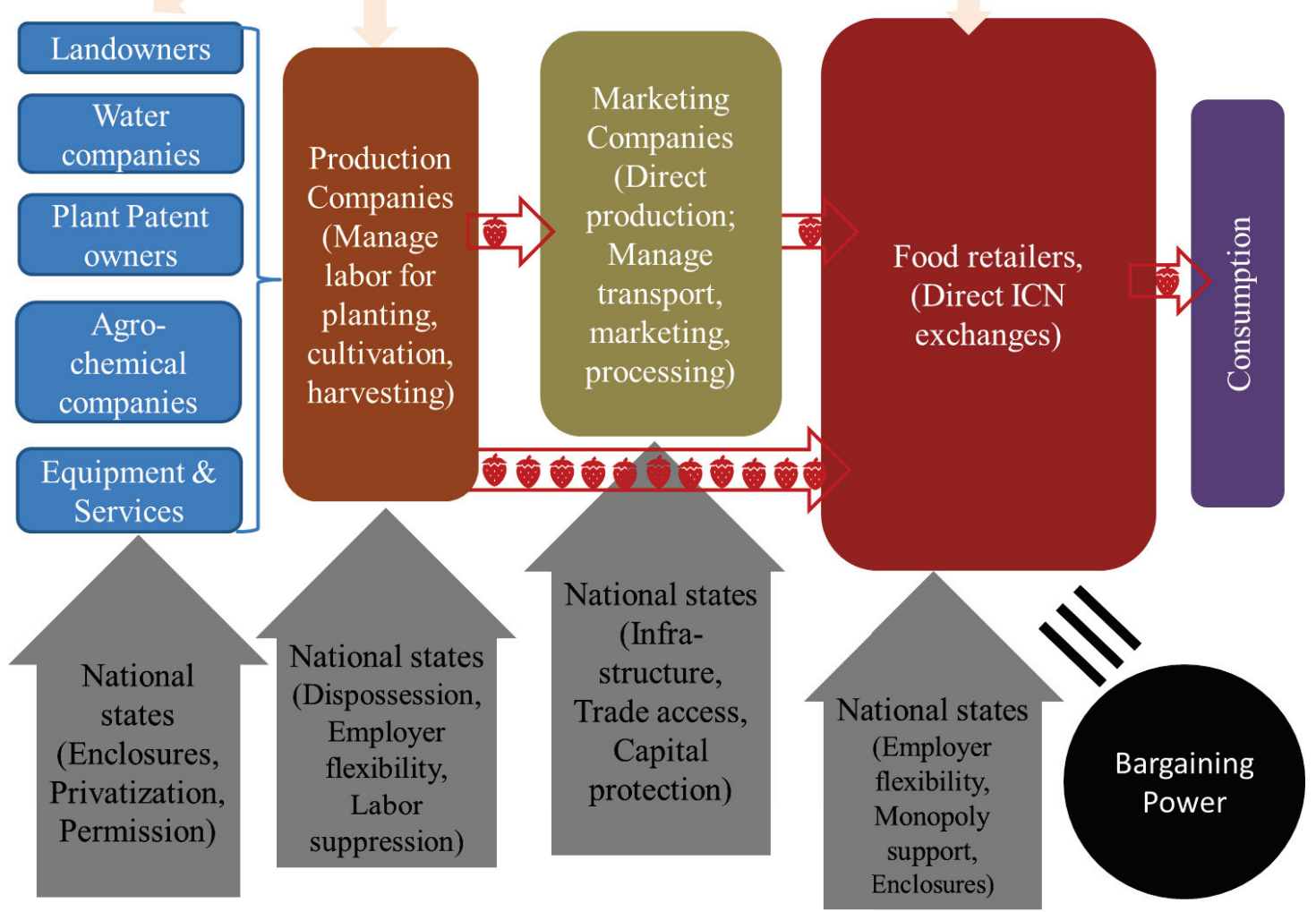

Figure 1: A simplified strawberry international commodity network

\section{Structuring Low Workplace Bargaining Power of Workers}

The organisation of capital flowing through the strawberry sector's production sites in San Quintín concentrates value in retail and marketing firms, empowering their direction of exchanges throughout production, distribution and sales processes. In its neo-liberal turn following debt crises and in exchange for access to international finance, the Mexican government repeatedly devalued its currency, liberalised capital accounts, privatised land, water and industries, reduced spending on education and health care, and shifted subsidies from small agricultural producers to agribusiness exporters (Echánove, 2001; SAPRIN, 2004; Velasco, Coubès and Zlolniski, 2014; Zlolniski, 2019).

Adverse Effect Wage Rate for employment of workers through the H-2A programme in California was $\$ 14.77$ per hour; strawberry pickers represented by Familias Unidas por la Justicia earned $\$ 16-\$ 18$ per hour in Washington State. As older workers in San Quintín recalled in interviews, until the mid-2000s "there wasn't a problem, such a strong border issue"; "one could come and go across the border. Since the early 2000s, the US Department of Homeland Security increased arrests and deportations of undocumented immigrants and pushed border crossers into the Sonoran Desert by building walls and increasing border patrols (ACLU, 2020). 
With the North American Free Trade Agreement (NAFTA), Mexico's government consolidated structural adjustment policies, reduced tariff barriers and strengthened protections for international investors via investor-state dispute settlement and intellectual property rights commitments. In response, nationals from the states of Jalisco, Michoacán and Sinaloa invested in strawberry production in San Quintín, like the García family that accumulated 19000 hectares of formerly communal (ejido) land in the valley (Martínez Novo, 2004: 217). US capitalists also invested. Driscoll's, through its strategic partner Reiter Affiliated Companies (RAC), ${ }^{6}$ established Berrymex, which became the dominant berry company of Mexico and contributed to Driscoll's capture of market share. Driscoll's CEO reported at the time, "We have developed and patented our own plant varieties, and would not have risked bringing them to Mexico unless NAFTA protected our patents" (Crawford, 1997). By the late 2010s, Driscoll's owned 28 per cent of strawberry patents, and accounted for an estimated one-third of US berry market sales and 60 per cent of organic strawberry sales (Lawrence, 2015; Goodyear, 2017; USPTO, 2020). Meanwhile, the US government gutted anti-trust law under the "consumer welfare" doctrine, ${ }^{7}$ and its approach to labour policy has all but encouraged employer coercion of workers against unionisation while protecting employers from penalties that might deter illegal anti-union activities (Lichtenstein, 2007, 2008, 2009; Pier, 2007). No company took greater advantage than Walmart, which began food sales in the 1990s with 30 per cent lower labour costs than unionised competitors, and by 2020 accounted for nearly one-third of US food sales (Lichtenstein, 2008). ${ }^{8}$

The concentrated market shares of the largest sellers and marketers of strawberries empowers them to direct capital away from the production process. While most berries from San Quintín are marketed by Driscoll's, a production manager explained that lack of capital is the only reason any agribusiness accepts the leading marketer's terms. Suppliers to Driscoll's plant its patented varietals, manage production according to its specifications, and pay 18-25 per cent commission for marketing services (Guthman, 2017; Interviews). The marketer's general council explained:

Growers are sort of like our manufacturing plants. We make the inventions, they assemble it, and then we market it, so it's not that dissimilar from Apple using someone else to do the manufacturing but they've made the invention and marketed the end product (cited in Goodyear, 2017).

Driscoll's market share benefited from Walmart's rise. As Walmart consolidated, it demanded yearround supplies and preferred fewer suppliers to reduce transaction costs (Mohapatra et al., 2010), supporting Driscoll's expansion to Mexico to offer year-round supplies from overlapping harvest seasons. While pushing expansion, Walmart also demanded price reductions. According to Driscoll's CEO, the retailer demanded that the supplier "take it from your other customers". Highlighting the position of the hundreds of production managers in Mexico supplying Driscoll's and Walmart, one manager reported, "With the buying power that they have ... they punish you

\footnotetext{
${ }^{6}$ Driscoll's owners, the brothers Garland and Miles Reiter, created Reiter Affiliated Companies in 1976. RAC manages contract berry production in North America, and Driscoll's markets all of the product.

${ }^{7}$ Instead of the competition-supporting intent of anti-trust laws, since 1982 US policy limited who could be regarded as a victim of monopoly power to consumers and the application of the laws to protecting the lowest price to consumers, and established an effectively unprovable standard for plaintiffs alleging predatory pricing (Lynn, 2006; Orbach, 2011; Olson, 2014; Edlin, 2017).

8 Walmart's US grocery sales of $\$ 208413000000$ accounted for 32 per cent of total US grocery revenue (Fernandez, 2021; Walmart, 2021). Walmart's average labour costs decreased nearly 1 per cent from 1971 to 2008 (Brea-Solís, Casadesus-Masanell and Grifell-Tatje, 2015).
} 
some with the price". Another production manager underscored, "Consolidation of [the] customer base reduces opportunities to pass along cost increases". The extraction of value from production lowers the amount of capital over which production workers and managers might bargain. As indication of the direction of capital flows, typical wage rates in San Quintín were approximately 3.9 per cent of US strawberry retail prices in $2020 .{ }^{9}$

Further limiting capital flowing through production companies is their reliance on input suppliers whose market share also empowers them to set prices. Ten companies own 70 per cent of strawberry plant patents; one, Corteva, dominates fumigant manufacturing; two, Yaffa and CQM, dominate fertilisers; and some of the largest chemicals companies worldwide dominate fungicides and pesticides. ${ }^{10}$

In addition to market concentration, the international network organisation of the strawberry sector insulates the retailers and marketers from disruptions of the valorisation process. When workers went on strike in 2015, the retail and marketing buyers shifted to alternate suppliers. With San Quintín's harvest disrupted that year, annual production for 2015 decreased in Mexico and grew in the United States, where it had decreased the previous three years (FAO, Undated b; SIAP, 2020). The following year, Mexican production decreased in San Quintín (down 14 per cent) while increasing in the states of Michoacán (35 per cent) and México (28 per cent) (SIAP, 2020). Following the strike, an attempt to lead a boycott of Driscoll's fell flat, with the harvest workers blocked by immigration laws from traveling to primary US sales locations to develop the boycott committees that have facilitated successful boycotts elsewhere. ${ }^{11}$ Thus, the San Quintín workers' disruptive capacity was blunted, and the strike was contained as a problem only for production managers in San Quintín to manage.

\section{Structuring Low Labour Market Bargaining Power of Workers}

The organisation of a surplus and differentiated labour market supplying strawberry production in San Quintín has determined the growth of the sector. As just described, production managers have high labour costs relative to total operating costs and depend on price-elastic input and output exchanges. Thus, their competitiveness turns on capacity to replace workers, a condition

\footnotetext{
${ }^{9}$ These approximations are using $\$ 3.08$ for a pound of berries sold in US retail and, for harvest wage rates, the average rate reported by workers and managers interviewed in San Quintín.

${ }^{10}$ Driscoll's, the Regents of the University of California, Plant Sciences, Inc., and Plantas de Navarra S.A. (Planasa, aka Societe Civil Darbonne and Darbonne Pepiniere, SAS) alone received 56 per cent of strawberry plant patents from the US government (USPTO, 2020). Corteva (previously the agricultural unit of DuPont, sold to complete the DuPont-Dow merger in 2019) owns the trademark for Telone ${ }^{\circledR}$, the compound of chloropicrin and 1,3-dichloropropene used as a fumigant in commercial strawberry production. Yaffa and CQM control as much as 80 per cent of the fertiliser market, according to another production company manager interviewed. Widely used fungicide Carbendazim and pesticide Bifenthrin are manufactured by massive multinational corporations: BASF, DuPont, Bayer CropScience, Jiangsu Lanfeng Bio-Chem, Lianyungang Jindun Agrochemical, NingXia Sanxi Chemical, Anhui Guangxin Agrochemical Group, AnHui JinTai Pesticides Chemical, Bailing Agrochemical, Trustchem, Jiangsu Sinamyang Crop Science, Yangzhou Pioneer Chemical, Hunan Haili Chemical Industry.

${ }^{11}$ In 1970, the United Food Workers sent US citizens throughout North America and Europe to set up boycott committees that pressured employers into negotiating contracts with the union, and in 2016 Familias Unidas por la Justicia travelled throughout the US west coast to set up boycott committees that pressured their employer into conceding to a union election (Fischer-Daly, 2021).
} 
established through political decisions mediated by racialism and patriarchy.

National state dispossession of primarily indigenous peoples from livelihoods based on communal land use has compelled millions into wage labour, tens of thousands of whom harvest berries in San Quintín. With the agrarian reform of 1992, the Mexican government replaced the promise of access to land, established in the Mexican Revolution, with encouragement of employment in agribusiness (Lara Flores, 2005). It extended capitalist property rights over ejidos, communally owned lands transferred hereditarily, on which reciprocity directs commerce (Velasco et al., 2014: n. 114; Interviews). Government fiscal support for agriculture, most of which was directed to small producers, dropped 60 per cent in the 1980s (Lara Flores, 2005). The reduction of trade barriers under NAFTA brought a flood of US-subsidised corn, the dominant grain consumed in Mexico, foreclosing ejido-based livelihoods. Non-remunerated employment in agriculture and forestry fell 58 per cent between 1991 and 2007, meaning some 4.9 million people, mostly of indigenous heritage, were dispossessed of the means of production (Weisbrot, Lefebvre and Sammut, 2014: 13). As workers explained, in indigenous communities where the ejido system predominated, peasants were suddenly put into competition with multinational corporations and yet were provided with "no means to sell products, for the lack of a highway, no airport, roads, nothing"; "there was everything there - chickens, birds, rabbits, lettuce, vegetables, radishes, fruits - so much, but there's no market". Meanwhile, export agriculture never offered the possibility of absorbing all of the new wage workers; it offered seasonal wage labour for some workers and contributed to inflated living costs by prioritising export commodities over domestic food supplies (Lara Flores, 2005).

Production companies in San Quintín recruited the new wage workers from predominantly indigenous communities as seasonal labour. Starting in the 1980s, employers sent labour recruiters to bring workers from the states of Oaxaca, Guerrero, Durango, Sinaloa and Sonora (Lara Flores, 2005; Zlolniski, 2010; Velasco et al. 2014). Employers sent workers away after harvests, establishing a migrant labour force that allowed for the externalisation of labour reproduction costs to workers' home communities, depressing wage bills below local living costs (Burawoy, 1976; Kearney, 1988). Wage-seekers followed the recruiters and began to arrive in San Quintín on their own, becoming the majority in the 1990s (Martínez Novo, 2004). By 2000, the industry demanded a more stable workforce as winter strawberries became the most valuable export and buyers required ever more specific production practices (Velasco et al., 2014; Zlolniski, 2019). The estimated 80000 workers now living in San Quintín and working in its agricultural export industry include second and third generations of those displaced from southern states. By local workers' estimates, at least 80 per cent of the sector's workforce resides in and considers San Quintín home. A former regional official of the National Commission of Indigenous Peoples estimated the same percentage of the municipality's population are indigenous peoples from forty-three different groups. The settling of the workforce locally forced employers to reproduce control over labour costs without migrant labour, achieved over the decades of strawberry sector growth with social orders and selective law enforcement.

Indicative of their ability to replace workers, employers discharge workers every one to three months, confident that enough workers are available, given few alternatives and negligible savings due to low wage rates. In addition to ensuring low worker bargaining power in the marketplace, employers' dismissal practice reduces remuneration duties. As a local labour lawyer explained, national law stipulates that all workers become permanent, and therefore entitled to more benefits, after working for at least four days per week for twenty-six weeks. Bolstering the labour surplus and lack of alternative employment in San Quintín have deepened dependency on income from 
fieldwork. In the valley, access to non-agribusiness, agribusiness services or management employment is limited, particularly for indigenous and women residents (Velasco et al., 2014). Packhouses offer "dizzying", often eighteen-hour shifts, as a young female worker of mixed European and indigenous heritage recounted. Fewer still attempt their own businesses. A couple explained that from their convenience store, "everything earned now is not to work outside", a strategy threatened by the expansion of international corporations. ${ }^{12}$ More workers used to migrate to work in the United States, but that option has become increasingly limited to those who can obtain an H-2A visa. ${ }^{13}$ US employers test workers' fieldwork skills prior to committing, have the ability to send workers back at any time, and are known to rehire only the fastest workers (Zlolniski, 2019: 103; Interviews).

Underpinning the displacement of peasants and limitations on their socio-economic and political mobility are social orders that subordinate indigenous peoples and women. The construction of the fieldworker identity imposed on indigenous peoples of southern Mexico is a racialism process necessarily involving much deconstruction, ${ }^{14}$ conveyed here broadly by reference to indicative strategic actions. European colonists annihilated most indigenous people, then placed survivors in planned settlements (Kearney, 1988). The Mexican state then constructed a national mestizo identity, a process of integration and nation-building that marginalised indigenous peoples (Cardoso de Oliveira, 1992; Barabas and Bartolomé, 1999). The Mexican Revolution formally established democratic governance and the ejido system, and established the corporatist system of state control over wage labour (Bensusán, 2020). As part of its neo-liberal turn, the Mexican president announced the privatisation of lands in 1991 by declaring, "There will be employment in the fields and this means more salaried work" (quoted in Lara Flores, 1996), reinforcing the ascription of fieldwork onto people categorised as indigenous.

In support of its low-cost labour demand, San Quintín's strawberry sector has adapted the "constitution of [indigenous peoples] as a class, and the class relations which ascribe it, function as race relations" (Hall, 1996: 341). Substituting their diverse historical experiences, primarily the state and employers, and to a degree some of the newly proletarianised workers themselves, co-created an idealised identity of indigenous fieldworkers (Martínez Novo, 2004). The ahistorical, reductionist identity assigned to diverse indigenous peoples emerges in public discourse, the press and discussion with managers, state officials and workers. The stereotype is that indigenous means short and thus naturally adept at stooped fieldwork, unskilled, frugal and thus more than content with any wage, accustomed to impoverished living conditions as "traditional", and docile and thus nearly incapable of resistance (Martínez Novo, 2004; Interviews). Thus, a manager noted, "Normally people know how to pick [strawberries], but if people come from Chiapas and don't know, then we have a little school to show", using the Mexican state most identified with contemporary resistance to colonialism as a euphemism for unskilled. To reinforce the trope of

\footnotetext{
${ }^{12}$ Following the lifting of barriers to competition with the national oil and gas corporation PEMEX in 2015, multinational corporations have introduced the gas station plus convenience store model that now dominates the trans-peninsular highway running through San Quintín.

${ }^{13}$ See footnote 5 .

${ }^{14}$ By racialism, I mean Cedric Robinson's (2000: 2) concept, "legitimation and corroboration of social organization by reference to the 'racial' components of its elements". As Minkah Makalani (2021) points out, Robinson's concept of racialism pushes us to see beyond the historically contingent manifestations of racism and to see the naturalisation of hierarchies that permeate all social structures, including modes of property relations.
} 
workers' gratefulness for employment in the fields, without offering evidence employers blamed "external groups and hooded men", federal intelligence agents blamed drug cartels, and politicians accused rivals of leading the 2015 strike (García Soto, 2015; Tijuana Noticias, 2015). Reflecting hegemonic "common sense" (Gramsci, 1996), the elites insinuated that indigenous people lacked the capacity to do so. Workers perceive that employers and government actors strategically construct a stereotype of vulnerable indigenous peoples, dependent on their patriarchal care. While managers express indifference, claiming "We give the opportunity to anyone who wants to learn", workers say, "We still live racism, which is the divider". Another interviewed worker and labour organiser elaborated on the ascription of fieldwork to indigeneity that many experience:

They know perfectly well that the poor people of Mexico, the indigenous, the people with fewer resources, their only means is through education. And they know that for me to send my children to school, I need a good salary. So they say, 'we cannot raise the salaries so high that he can send his children to school, because then we won't have workers'.

For indigenous women, subordinating forces intersect, providing an additional mechanism to suppress the market bargaining power of all workers by devaluing female, indigenous labour. Workers claimed that there had been widespread sexual abuse as agribusiness developed in the 1990s and 2000s. Management remains dominated by men with European heritage, and employee opportunities are divided, with pack houses hiring predominantly women with European heritage and, in fields, reserving tractor-driving, irrigation and other "technical" and better-remunerated positions for men. A worker self-identified as an indigenous woman summarised, "The foremen did not treat us well - a lot of assault, many vulgar, gross language, and yes, physical assault as well". Others scoffed at supervisors who "have their lovers [whom] they put ... in the lighter jobs", such as fruit checking. An organiser explained that only one company began hiring women into all non-managerial positions in 2020. According to the company's manager, "Work results are better with women - not to say that there aren't hard women, but ... the man, we can be harder, and it can create problems for the companies", reproducing expectations of female docility. Referring to the multiple burdens endured, an indigenous woman worker explained, "You return to work because you have to feed the family".

\section{Reproduction of Weak Worker Structural Power through Selective Law Enforcement}

Selective law enforcement has encouraged the weak structural power of workers in San Quintín strawberry production by enhancing employer discretion while suppressing workers' collective action. As labour relations scholar Graciela Bensusán (2020) documented, the country's labour relations system passed through two periods of corporatism before adopting the current neo-liberal model. The government prioritised industrialisation and thus protected workers in select industries from 1917 into the 1970s, when it began to prioritise export-led development. Selective law enforcement, including support for collective bargaining avoidance, supported the capital growth strategy. In his aforementioned announcement of land privatisation, the Mexican president proclaimed, "The moment has arrived to recognize this situation and to promote the unionization of agricultural day labourers" (quoted in Lara Flores, 1996). The discourse defined fieldworkers as "day labourers" - that is, outside labour and social security laws. It further obfuscated the state's position. Far from protecting freedom of association and collective bargaining rights, the state was 
supporting employer protection contracts.

Employer protection contracts have proliferated in Mexico since the 1980s as a means for employers to avoid collective bargaining. The practice emerged out of the combination of regulations and norms granting employers substantial control in choosing their union counterpart on the one hand and concentrating power in union leadership without democratic praxis and accountability to members on the other (Bensusán, 2006). Under protection contracts, an employer pays a union entity to ensure that there is no independent worker collective action. When workers first began organising in the San Quintín Valley in the 1980s, employers responded by signing protection contracts, primarily with the Confederación de Trabajadores Mexicanos (CTM), the Confederación Regional Obrera Mexicana (CROM), and the Confederación Revolucionaria de Obreros y Campesinos (CROC) (Velasco et al., 2014: 237-239). In San Quintín, employers have typically paid the protectionist unions directly. Workers and Labour Secretariat officials interviewed in 2020 reported that they have never seen a representative of the protectionist unions. During the 2015 strike, employers' first response to the Alianza, whose demands included nullification of the protection contracts, was a proposal to avoid the Alianza and to sign a settlement with the protectionist unions. To date, employer protection contracts in agribusiness remain.

Reinforcing employers' bargaining power, legal ambivalence and under-enforcement turn on the concept of "day labourer". Workers throughout Mexico are entitled to healthcare, pensions, maternity leave, paid vacation, year-end bonuses, modest profit-sharing, job protection and indemnification for dismissal without just cause under social security and labour laws. For decades, studies documented the denial of these rights to agribusiness fieldworkers in San Quintín (Garduño, García and Morán, 1989; Lara Flores, 1996; Velasco et al., 2014). Meanwhile, the government has moved slowly since the 1980s to include temporary agricultural workers under labour and social security laws, eventually settling on a definition of temporary agricultural worker as contracted for less than twenty-seven weeks, and finally requiring employers to comply with duties under labour and social security laws in 2012 (Velasco et al. 2014: 195-200). Current law stipulates that workers become permanent, and therefore entitled to full legal rights and benefits, after working at least four days per week for twenty-six weeks. Yet legal enforcement is lax. Workers interviewed in 2020 responded with incredulity to the question of any government inspector. A group of women replied in near chorus, "What do you mean, their presence? You don't see them. What government? We don't see any agencies". Another worker reported, "It seems that the company doesn't allow inspectors to enter". An independent union organiser explained that workers who pursue remediation through STPS are often encouraged by its representatives to accept half of what they are owed, because pursuing full payment would likely entail hiring a lawyer and enduring a multi-year process. The legal ambivalence and underenforcement shield employers from higher wage bills, protection strengthened by suppression of worker collective action.

Additionally, while workers' right to strike is established in Mexico's Constitution (Article XVII) and Federal Labour Law (Article 2), the federal police forcefully suppressed the 2015 strike in San Quintín. As strikers recalled, the first day began with workers blocking the highway and communicating with the police and ended with a flood of municipal and federal police using antiriot tactics. The federal government documented that police used force on strikers, jailed dozens, and cut off radio, phone and Internet service in the valley, justifying the response by exaggerating the few instances of vandalism (SEGOB, 2017; Interviews). The state's forceful response sent thousands of workers home; after a few days, most returned to work. Subsequently, during negotiations to settle the strike, federal police raided the neighbourhood of Lomas de San Ramón, 
known locally for robust community organising. Police arrived in armoured vehicles, entered homes and physically assaulted residents, who responded by burning one of the armoured vehicles and the local police station, and barricading the neighbourhood (SEGOB, 2017; Interviews).

Even as the Mexican government introduced reforms supporting independent union collective bargaining, actions have indicated ongoing suppression of worker organising, especially in agribusiness. The government amended the national constitution in 2017, activated labour law reforms in 2019, and committed to increased accountability for enforcement in the United StatesMexico-Canada Agreement (USMCA) in 2020. ${ }^{15}$ As of 2020, the Federal Labor Law prohibits employer interference in union and collective labour activities, grants workers freedom to affiliate and disaffiliate from unions and elect union executive board members for limited tenures, protects the right to union and collective labour activities by informal workers, prevents government interference with the new Federal Centre for Labor Conciliation and Registration, requires mechanisms for worker control over union decision-making, and requires worker support through voting for union representation and collective bargaining agreements (Bensusán, 2020: 19-23). The legislation also stipulated that all unions must comply with the new laws, including through a democratic election of executive board members within 240 days and by amending procedures for workers to vote on collective agreements by 2 May 2021 (Bensusán, 2020: 22). The USMCA mechanism to support enforcement does not yet include agriculture, ${ }^{16}$ and events since the reforms indicate ongoing suppression of unionism in San Quintín. In 2019, an employer fired twelve security guards; SINDJA assisted the workers to file a complaint with STPS; the employer invited the workers to return to work, where thugs beat them; the union assisted the workers to file a criminal complaint; a unionist's home was burned down; and no investigations were conducted.

15 The USMCA provides mechanisms for pressuring the Mexican government and employers to comply with the new labour laws. The three signatory governments committed to uphold International Labour Organization (ILO) core labour standards, including the right to strike, in Chapter 23 of the USMCA. This means that violations of these standards are subject to the same dispute settlement system as other provisions of the agreement, and can lead to arbitration and sanctions on a government as last steps of the complaint process. For disputes alleging violations, the USMCA requires its dispute settlement panel to assume that the violation affects trade, unless the government proves otherwise, and does not require that the violation gave an employer a competitive advantage. In the Dominican Republic - Central America United States Free Trade Agreement, a complainant had to prove that the labour standards violation was affecting trade and conferred a competitive advantage to an employer, positions of the US-Guatemala panel that prevented findings and remedial action. Furthermore, the USMCA establishes the Facility-Specific Rapid Response Labor Mechanism, which permits complaints by the US or Canadian government against an employer in Mexico for violations of freedom of association and collective bargaining rights to a panel, with the mandate to impose remedial measures, including sanctions such as suspension of trade preferences. The USCMA permits complaints by the Mexican government against a US or Canadian employer "only with respect to an alleged Denial of Rights owed to workers at a covered facility under an enforced order" of the National Labor Relations Board or the Canada Industrial Relations Board, respectively. Claims can be brought against Mexican employers only with respect to an alleged Denial of Rights under legislation that complies with Annex 23-A (Worker Representation in Collective Bargaining in Mexico) (USCMA Art. 31-A.2 footnote 2, Art. 31-B.2 footnote 5). However, this rapid-response mechanism applies only to "priority sectors", currently including manufacturing, services and mining. While the government signatories can add sectors, it would require strong pressure to convince the US government to propose the extension and to convince the Mexican and Canadian governments to agree. (Santos, 2019; USMCA, 2020).

16 See footnote 15. 


\section{Structural Containment of the Largest Strike in Mexican Agribusiness History}

The mass strike led by the Alliance of National, State, and Municipal Organizations for Social Justice in San Quintín during the peak strawberry harvest in 2015 demonstrated the material operations of the strategically organised balance of structural power. The organisation of networked capital, a surplus, the differentiated labour market and national-state support for agribusiness control over labour limited the effects of disruption of production and transportation and reproduced low-cost production supplying the North American strawberry sector. Strikers compelled the state to register the independent union SINDJA, and employers to increase wages and registration in IMSS. Five years on, inflation eroded the modest wage increases, most workers remained unregistered in IMSS, and all the workers lacked independent union representation in collective bargaining with employers. The strike and its outcomes evince the historically constructed balance of structural power as the engine of the strawberry sector's growth.

Workers exercised their capacity to disrupt production and transportation of strawberries on which the lead companies of the sector depended for sales during the North American winter. San Quintín's harvest peaks from mid-February through mid-April, when strawberries are trucked daily to US markets; 75-80 per cent of those marketed by Driscoll's are shipped the day they are picked (Broussel, 2011). Strikers shut down production on March 17 and occupied the trans-peninsular highway, blocking transportation along its sixty-two mile stretch through San Quintín. With Baja California accounting for nearly one-quarter of Mexico's strawberry production, the crop accounting for 35 per cent of the state's income from agriculture, and production companies anxious over immediate financial losses and their low-cost labour competitiveness, government officials from the state and national levels and the employers' association Agricultural Council of Baja California (Consejo Agrícola de Baja California, CABC) responded to preserve the sector's growth.

The national state and the $\mathrm{CABC}$ acted to limit the immediate and long-term effects of the strike. The national police response during the first days of the strike sent most strikers home, and its use of force during subsequent negotiations further pressured workers to concede to employers' terms of settlement. A young mother recalled, "I knew that there was a strike. I didn't participate. I had to care for my children.... Also, if you joined the strike, you risked being fired. They fired everyone who participated". While not all were fired, dismissals combined with police use of force conveyed the message that workers would not be permitted to exercise strike rights. A labour organiser reflected, "That's when I realised that the people were not well organised to deal with that situation".

Further reducing workers' ability to sustain the strike, most lacked income for basic needs. Workers recalled, "People didn't have enough to get by, and it had been years since they increased wages". Meanwhile, "gas pressed us because it went up, eggs ... everything was getting more expensive, and 90 pesos [per day] didn't cover it ... we were fed up". Neither the Alliance nor the many social movement organisations that expressed support were in a position to sustain striking workers. $^{17}$

\footnotetext{
${ }^{17}$ Organisations that issued statements, and in some cases provided some funds included: Frente Indígena de Organizaciones Binacionales, Central Independiente de Obreros Agrícolas y Campesinos, Central Campesina Cardenista, Unión Nacional de Trabajadores, Nueva Central de Trabajadores, Sección XXII de la Coordinadora Nacional de Trabajadores de la Educación, Ejército Zapatista de Liberación Nacional, Frente Popular Revolucionario, Familias Unidas por la Justicia, United Farm Workers, Farm Labour Organizing Committee, and the AFL-CIO.
} 
Additionally, workers' ability to pressure the marketing and retail firms directing the strawberry sector was diminished. Lead firms shifted to alternative locations for supplies. Workers' political immobility diminished their ability to set up boycott committees in the US market.

Furthermore, while the Alliance organised workers across diverse ethnic groups, patriarchal divisions emerged internally. One female strike organiser reported, "The Alliance broke because power concentrated in three people ... they excluded us". Another recalled, "I saw that I was the only woman ... I invited the leaders and their spouses to dinner to get to know each other", and none came.

While thousands of workers marched to reiterate strike demands in May (Cruz, 2016: 208), leverage had diminished. A cessation of collective action thereafter indicated that workers understood they were at the bottom of the balance of structural power.

With workers' disruptive power contained, the strike settlement reproduced the terms and conditions of employment that supported employers' competitiveness. Employers first proposed negotiating with the protectionist unions CTM, CROM and CROC, then conceded standing to the Alliance. They countered strikers' demands for an increase from the prevailing 120-peso to 300peso daily rate with a proposed 12 per cent wage increase and registering workers in IMSS. Intermittent negotiations dragged on for nine weeks. On June 4, negotiations concluded. Under the settlement, employers agreed to raise wages 15 per cent, to register workers in IMSS, to cease employing children and not to retaliate against strikers. Government officials agreed to release detained strikers, initiate housing, nutrition and health programmes, and register SINDJA. The settlement further divided strike leaders by sustaining the "integrated" pay modality under which wages and benefits are not itemised, obfuscating compliance with legally required benefits. Several Alliance negotiators refused to sign. One recalled,

Our fight ended June 4 ... the document said at the time that pay was going to be integrated ... that benefits were going to be included, and the fight was that they would be apart ... I didn't agree that you should sign ... you have to consult ... if they [workers] are in agreement that you sign the document with its conditions, then good, but they're the only ones who can decide.

Five years later, protection contracts continued to block collective bargaining; the government had not invested in the social programmes that it had committed to in negotiations; and employers registered more, but not even half, of all workers in the social security system. Table 1 summarises the gaps between legal rights and terms and conditions of employment in 2020.

\section{Concluding Observations}

The terms and conditions of employment, and the outcomes of the mass strike in strawberry production in San Quintín indicate more traction of structural power conceptualised as historically (re)produced. Mexico did not export strawberries prior to the 1980s. Thirty years later, the country supplies most berries imported into the United States for wintertime sales. The environmental and geographic conditions make San Quintín conducive to the strawberry export business; however, making the sector profitable entailed dispossession of largely indigenous peasants; privatisation of land and water; direct subsidies; NAFTA's trade, investment and intellectual property rights regimes; reproduction of the subordination of indigenous peoples and women; enhanced employer discretion; and suppression of worker collective action. Far from transcendental, these are strategic actions of capitalists, national states and workers striving to preserve their livelihoods. 
Table 1: Legal versus actual employment conditions, strawberry sector, San Quintín, 2020

\begin{tabular}{|c|c|c|}
\hline Terms & Legal Requirement & 2020 Status \\
\hline $\begin{array}{l}\text { Freedom of association and } \\
\text { collective bargaining rights }\end{array}$ & $\begin{array}{l}\text { ILO Conventions No. } 87 \text { and } 98 \text { articulated in } \\
\text { Federal Labour Law Art. 357, } 357 \text { bis, } 358 .\end{array}$ & $\begin{array}{l}\text { Blocked by employers' } \\
\text { protection contracts since } \\
\text { 1980s. }\end{array}$ \\
\hline Wages & $\begin{array}{l}\text { Constitution Art. VI stipulates minimum wage to } \\
\text { be a living wage. }{ }^{18}\end{array}$ & $\begin{array}{l}\$ 18-\$ 28 \text { per day during } \\
\text { harvest; } \$ 12 \text { per day off-season } \\
\text { compared to } \$ 11 \text { per day costs } \\
\text { for water, food, gas, and } \\
\text { electricity }{ }^{19}\end{array}$ \\
\hline Social security & $\begin{array}{l}\text { Social Security Law Art. } 15 \text { requires employer } \\
\text { registration of workers within five days when } \\
\text { working } 4+\text { days per week. }\end{array}$ & Less than $40 \%$ registered. ${ }^{20}$ \\
\hline Overtime wage rates & $\begin{array}{l}\text { Federal Labour Law Art. } 67 \text { requires double } \\
\text { regular payrates for more than eight hours in a } \\
\text { day; Art. } 68 \text { requires triple pay for more than } \\
\text { nine extra hours in a week. }\end{array}$ & \multirow{4}{*}{$\begin{array}{l}\text { Most fieldworkers reported } \\
\text { non-compliance. } \\
\text { Some fieldworkers, tractor } \\
\text { drivers and security guards } \\
\text { reported partial compliance. } \\
\text { "Integrated salary" pay } \\
\text { modality obscures employer } \\
\text { compliance by not itemising } \\
\text { amounts paid. }\end{array}$} \\
\hline Paid breaks & $\begin{array}{l}\text { Federal Labour Law Art. } 64 \text { requires a paid } \\
\text { thirty-minute break for workers who cannot } \\
\text { leave the workplace; Art. } 69 \text { requires a paid day } \\
\text { off for every six days worked. }\end{array}$ & \\
\hline Paid vacation & $\begin{array}{l}\text { Federal Labour Law Art. } 76-81 \text { require paid } \\
\text { vacation. }\end{array}$ & \\
\hline Annual bonus & $\begin{array}{l}\text { Federal Labour Law Art. } 87 \text { requires annual } \\
\text { payment equivalent to fifteen days wages or } \\
\text { amount proportional to days worked. }\end{array}$ & \\
\hline Discrimination & $\begin{array}{l}\text { Federal Labour Law Art. } 2 \text { prohibits } \\
\text { employment discrimination. }\end{array}$ & $\begin{array}{l}\text { Most companies reserve } \\
\text { higher-paid jobs for men. }\end{array}$ \\
\hline $\begin{array}{l}\text { Occupational safety and } \\
\text { health }\end{array}$ & $\begin{array}{l}\text { Federal Labour Law Art. } 3 \text { requires working } \\
\text { conditions that assure workers' health; Art. } 51 \\
\text { grants workers the right to refuse dangerous } \\
\text { work; Art. } 132 \text { requires employers to prevent } \\
\text { occupational accidents and diseases; Art. } 343-\mathrm{C} \\
\text { requires employers to inform workers of health } \\
\text { risks. }\end{array}$ & $\begin{array}{l}\text { Fieldworkers reported lack of } \\
\text { information from employers } \\
\text { on chemicals applied to fields } \\
\text { and refusal by public hospitals } \\
\text { to report chemical-exposure } \\
\text { cases. }\end{array}$ \\
\hline Parental leave & $\begin{array}{l}\text { Federal Labour Law Art. } 170 \text { grants mothers six } \\
\text { weeks' leave prior to and after birth, and six } \\
\text { weeks after adoption; Art. } 132 \text { grants fathers five } \\
\text { days paid leave after either. }\end{array}$ & $\begin{array}{l}\text { Fieldworkers reported } \\
\text { arbitrary employer compliance. }\end{array}$ \\
\hline
\end{tabular}

Source: author's compilation based on Mexican statutes and interviews with workers and managers.

18 The Political Constitution of the United States of Mexico (Art. VI) states the minimum salary paid to workers should be sufficient, accounting for regional conditions, to satisfy normal needs in the life of the worker, their education and honest pleasures, considering the worker as head of a family - contemporarily the meaning of "living wage" (Anker, 2011.)

19 Workers ( $\mathrm{n}=50$ ) reported spending 160 pesos on water, 1211 on food, 101 on gas and 85 on electricity per week.

${ }^{20}$ Local IMSS office data showed a total of 46165 employees registered in the social security system, 6000 of whom were registered as permanent workers; of those registered as temporary workers, 10000 were in agriculture. Conservatively assuming 16000 agricultural workers registered on any basis (despite the obviousness that some number of the 6000 permanent workers are in other industries) would suggest that 40 per cent of the 40000 workers employed in San Quintín agriculture were registered in IMSS in 2020, most only for part of the year. 
Problematising structural power as a dynamic complex of strategic action in a particular place and era avoids deducing analysis from extant theory and supports explications grounded in historical specificity. Attention to the organisation of companies' boundaries and capacities to direct exchanges, racialised and gendered subordination of groups, and selective law enforcement provokes understanding of structural power as a process of class struggle, not as a given state. While structural power is often identified as a given for most employers or for workers in sectors such as ports, rail and airways, and just-in-time apparel, employers' power is historically organised, and more workers are positioned to disrupt capital accumulation processes as competition motivates and international policies facilitate tightly integrated production, circulation and consumption of commodities internationally. The outcomes of the 2015 strike in San Quintín highlight the limits of interpreting structural power as disruptive capacity within given boundaries, reminding us that the boundaries themselves must become targets in order to establish new social relations of production.

Historicising structural power clarifies the means to alter terms and conditions of obtaining life's necessities. The organised international network of capital, creation of a surplus, and differentiated labour market and selective law enforcement are strategic actions that contained the disruptive power of workers in San Quintín. Considering the national state's dispossession and export orientation and international network organisation of capital, state violence and lead-firm self-insulation from the strike were likely. In addition to the formidable organisation of the strike, workers may have increased their leverage in negotiations had they limited workers' exposure to and thus intimidation by violence, and/or galvanised broader support around such abuse, and organised transport and retail workers into solidarity actions. In conclusion, the case suggests that a historical reading of structural power illuminates a broader horizon for collective action to alter class relations.

\section{References}

American Civil Liberties Union (ACLU) (2020) Justice-Free Zones: U.S. Immigration Detention Under the Trump Administration. $\quad \underline{\text { https://www.aclu.org/report/justice-free-zones-us-immigration-detention-under- }}$ trump-administration (accessed 2 January 2021).

Anker, R. (2011) Estimating a Living Wage: A Methodological Review. ILO Conditions of Work and Employment Series No. 29. Geneva: ILO.

Arteaga, A. and J. Carrillo (1988) Automóvil: Hacia la flexibilidad productiva. El Cotidiano, 21: 79-88.

Barabas, A. and M. Bartolomé (eds.) (1999) Configuraciones étnicas en Oaxaca. Perspectivas etnográficas para las autonomías, 3 tomos. Ciudad de México: Instituto Nacional de Antropología e Historia (INAH) and Instituto Nacional Indigenista (INI).

Bensusán, G. (2000) El modelo mexicano de regulación laboural. Mexico: FES/Plaza and Valdés/FLACSO/UAM-X.

Bensusán, G. (2006) Diseño Legal y desempeño real: instituciones labourales en América Latina. Ciudad de México: UAM-X/Editorial Porrúa.

Bensusán, G. (2020) The Transformation of the Mexican Labour Regulation Model and its Link to North American Economic Integration. ILO Working Paper 15. Geneva: ILO.

Bensusán, G. and L. Reygadas (2000) Relaciones labourales en Chihuahua: un caso de abatimiento artificial de los salarios. Revista Mexicana de Sociología, 62(2): 29-57.

Bonnell, V.E. (1980) The Uses of Theory, Concepts and Comparison. Society for Comparative Study of Society and History, 22(2): 156-173. 
Brea-Solís, H., R. Casadesus-Masanell and E. Grifell-Tatje (2015) Business Model Evaluation: Quantifying Walmart's Sources of Advantage. Strategic Entrepreneurship Journal, 9: 12-33.

Broussel, L. (2011) Strawberry Fields Forever. Congress of Industrial Organizations (CIO), 5 June 2011.

Burawoy, M. (1976) The Functions and Reproduction of Migrant Labour: Comparative Material from Southern Africa and the United States. American Journal of Sociology, 81(5): 1050-1087.

Cardoso de Oliveira, R. (1992) Etnicidad y estructura social. Ciudad de México: CIESAS.

Centro de Análisis Multidisciplinario (CAM) (2015) Reporte de investigación 122. México: Se agudiza la superexplotación del trabajo. Continúa la pérdida del poder adquisitivo del salario de $9.65 \%$ con Peña Nieto. México D.F.: Universidad Nacional Autónoma de México.

Cook, R. (2011) Fundamental Forces Affecting the U.S. Fresh Berry and Lettuce/Leafy Green Subsectors. Choices: The Magazine of Food, Farm and Resource Issues. 26(4). https://www.choicesmagazine.org/UserFiles/ file/cmsarticle 201.pdf (accessed 11 January 2022).

Corbin, J. and A. Strauss (1990) Grounded Theory Research: Procedures, Canons, and Evaluative Criteria. Qualitative Sociology, 13(1): 3-21.

Crawford, L. (1997) New Pioneers Plough Ahead in Mexico: Nafta's Freer Trade is Promising Fruitful Returns to Farm Investors. Financial Times, 25 June 1997.

Cruz, J.E. (2016). El movimiento laboral-comunitario de los jornaleros del Valle de San Quintín. Acción colectiva en el sector agroexportador mexicano. Ciudad de México: Facultad Latinoamericana de Ciencias Sociales - Sede Académica de México.

Dicken, P., P.F. Kelly, K. Olds and H.W.-C. Yeung (2001) Chains and Networks, Territories and Scales. Global Networks, 1(2): 89-112.

Doellgast, V., N. Lillie and V. Pulignano (2018) Reconstructing Solidarity: Labour Unions, Precarious Work, and the Politics of Institutional Change in Europe. Oxford: Oxford University Press.

Echánove, F.H. (2001) Working under Contract for the Vegetable Agroindustry in Mexico: A Means of Survival. Culture and Agriculture, 23: 13-23.

Edlin, A.S. (2017) Predatory Pricing: Limiting Brooke Group to Monopolies and Sound Implementation of Price-Cost Comparisons. Yale Law Journal Forum, 127: 996-1012.

Environmental Working Group (EWG) (2019) Pesticides + Poison Gases = Cheap, Year-Round Strawberries. https://www.ewg.org/foodnews/strawberries.php (accessed 10 January 2022).

Fernandez, C. (2021) Supermarkets \& Grocery Stores Industry in the US - Market Research Report. IBISWorld. https://www.ibisworld.com/united-states/market-research-reports/supermarkets-grocerystores-industry (accessed 23 January 2021).

Fischer-Daly, M. (2021) Human Dignity and Power: Worker Struggles against Precarity in U.S. Agribusiness. Labour Studies Journal, 46(4): 369-393.

Food and Agriculture Organization (FAO) (Undated a) Chloropicrin. http://www.fao.org/3/x5042e/ x5042E0f.htm (accessed 10 January 2022).

Food and Agriculture Organization (FAO) (Undated b) FAOSTAT: Food and Agriculture Data. http://www. fao.org/faostat/en/ (accessed 10 January 2022).

Gallas, A. (2018) Class Power and Union Capacities: A Research Note on the Power Resources Approach. Global Labour Journal, 9(3): 348-352.

García Soto, S. (2015) San Quintín: ¿explotación, agitación o narco? El Universal, 21 March 2015.

Garduño, E., E. García and P. Morán (1989) Mixtecos en Baja California: el caso de San Quintín, Mexicali, México: Universidad Autónoma de Baja California.

Goodyear, D. (2017). Strawberry Valley. The New Yorker, August 14 (accessed 21 November 2019). 
Gramsci, A. (1996). Prison Notebooks, Volume II, edited by Joseph A. Buttigieg. New York: Columbia University Press.

Guthman, J. (2017) Life Itself Under Contract: Rent-seeking and Biopolitical Devolution through Partnerships in California's Strawberry Industry. Journal of Peasant Studies, 44(1): 100-117.

Hall, S. (1996) Race, Articulations, and Societies Structured in Dominance. In Black British Cultural Studies: A Reader, edited by A. Baker Houston Jr, Manthia Diaware and Ruth H. Lindeborg. Chicago and London: University of Chicago Press.

Harvey, D. (1999) The Limits of Capital. London: Verso.

Hopkins, T.K. and I. Wallerstein (1977) Patterns of Development of the Modern World-System. Review, 1(2): 111-145.

Instituto Nacional de Estadística y Geografía, Gobierno de México (INEGI) (2016) Anuario estadístico y geográfico de Baja California 2015. Aguascalientes City, México: INEGI.

Katz, H.C., T. Kochan and A. Colvin (2017) An Introduction to U.S. Collective Bargaining and Labour Relations. Fifth edition. Ithaca, NY: ILR Press.

Kearney, M. (1988) Mixtec Political Consciousness: From Passive to Active Resistance. In Rural Revolt in Mexico and U.S. Intervention, edited by Daniel Nugent. San Diego, CA: Center for U.S.-Mexican Studies.

Lara Flores, S.M. (1996) Mercade de Trabajo Rural y Organización Laboral. In Neoliberalismo y Organización Social en el Campo Mexicano, edited by H. Carton de Grammont. Mexico City: Universidad Nacional Autónoma de México.

Lara Flores, S.M. (2005) Mercado de trabajo rural y organización laboral. In Neoliberalismo y Organización Social en el Campo Mexicano, edited by H. Carton de Grammont. México D.F: Universidad Nacional Autónoma de México.

Lawrence, D. (2015) How Driscoll's is Hacking the Strawberry of the Future. Bloomberg Businessweek, 29 July 2015. https://www.bloomberg.com/cybersecurity (accessed 21 November 2019).

Lichtenstein, N. (ed.) (2007) Wal-Mart: The Face of Twenty-First-Century Capitalism. New York and London: The New Press.

Lichtenstein, N. (2008) How Wal-Mart Fights Unions. Minnesota Law Review, 92(5): 1462-1501.

Lichtenstein, N. (2009) Sam's World: How the Obama Era will Transform Wal-Mart. New Labour Forum, 18(2): 17-24. https://doi.org/10.4179/NLF.182.0000003

Lynn, B.C. (2006) Breaking the Chain. Harper's Magazine, 313(1874): 29-36.

Makalani, M. (2021) Cedric Robinson and the Origins of Race. Boston Review, February 1. http://bostonreview.net/race/minkah-makalani-cedric-robinson-and-origins-race (accessed 3 March 2021).

Mann, S.A. (1990) Agrarian Capitalism in Theory and Practice. Chapel Hill, NC: University of North Carolina Press.

Mann, S.A. and J.M. Dickinson (1978) Obstacles to the Development of a Capitalist Agriculture. Journal of Peasant Studies. 5: 466-481.

Martínez Novo, C. (2004) The Making of Vulnerabilities: Indigenous Day Labourers in Mexico's Neoliberal Agriculture. Identities, 11(2), 215-239.

Marx, K. (1989 [1863]). Reproducing the Concrete by Way of Thought. In Readings from Karl Marx, edited by Derek Sayer. London and New York: Routledge.

Mohapatra, S., R.E. Goodhue, C.A. Carter and J.A. Chalfant (2010) Effects of Forward Sales on Spot Markets: Pre-commitment Sales and Prices for Fresh Strawberries. American Journal of Agricultural Economics, 92(1): 152-163. 
Nowak, J. (2018) The Spectre of Social Democracy: A Symptomatic Reading of the Power Resources Approach. Global Labour Journal, 9(3): 353-360.

Olson, R.D. (2014) Lessons from the Food System: Borkian Paradoxes, Plutocracy, and the Rise of Walmart's Buying Power. In The Global Food System: Issues and Solutions, edited by William D. Schanbacher. Santa Barbara, CA: ABC-CLIO.

Orbach, B. (2011) The Antitrust Consumer Welfare Paradox. Journal of Competition Law \& Economics, 7: 133164.

Pier, C. (2007) Discounting Rights: Wal-Mart's Violation of US Workers' Right to Freedom of Association. Washington, DC: Human Rights Watch.

Piven, F. (2008) Challenging Authority: How Ordinary People Change America. Plymouth, MS: Rowman \& Littlefield.

Pulignano, V., N. Doerflinger and F. de Franceschi (2016) Flexibility and Security within European Labour Markets: The Role of Local Bargaining and the "Trade-offs" within Multinationals' Subsidiaries in Belgium, Britain, and Germany. ILR Review, 69(3): 605-630.

Pulignano, V. and A. Signoretti (2016) Union Strategies, National Institutions and the Use of Temporary Labour in Italian and US Plants. British Journal of Industrial Relations, 54(3): 574-596.

Reinecke, J. and J. Donaghey (2015) After Rana Plaza: Building Coalitional Power for Labour Rights between Unions and (Consumption-based) Social Movement Organisations. Organization, 22(5): 720740 .

Rhomberg, C. and S. Lopez (2021) Understanding Strikes in the $21^{\text {st }}$ Century: Perspectives from the United States. Power and Protest: Research in Social Movements, Conflicts and Change, 44: 37-62.

Robinson, C.J. (2000). Black Marxism: The Making of the Black Radical Tradition. Chapel Hill, NC: University of North Carolina Press.

Santos, A. (2019) Reimagining Trade Agreements for Workers: Lessons from the USMCA. https://ssrn.com/abstract $=3502815$ (accessed 14 January 2021).

Secretaría de Gobernación (SEGOB), Estados Unidos Mexicanos, Comisión para el diálogo con los pueblos indígenas de México (2017). Notas Informativas sobre el Conflicto de los Jornaleros Agrícolas del Valle de San Quintín, Ensenada, Baja California, Marzo 2015 - Mayo 2017.

Servicio de Información Agroalimentaria y Pesquera (SIAP), Gobierno de México (2020) Datos Abiertos Estadística de Producción Agricola. http://infosiap.siap.gob.mx/gobmx/datosAbiertos a.php (accessed 19 November 2020).

Shelman, M. (2017) Driscoll's: Harnessing Digital Technology to Deliver Delight. California Agribusiness Executive Seminar, University of California, Davis.

Silver, B. (2003) Forces of Labour: Workers' Movements and Globalization Since 1870. Cambridge: Cambridge University Press.

Structural Adjustment Participatory Review International Network (SAPRIN) (2004) Structural Adjustment: The SAPRI Report - The Policy Roots of Economic Crisis, Poverty and Inequality, London: Zed Books.

Tijuana Noticias (2015) Respuesta de Jaime Martínez Veloz, acerca de las acusaciones del Senador Ernesto Ruffo Appel. Tijuana Noticias, March 23.

Tourte, L., M. Bolda and K. Klonsky (2016) The Evolving Fresh Market Berry Industry in Santa Cruz and Monterey Counties. California Agriculture, 70(3): 111.

United Nations (UN) Comtrade. (Undated) UN Comtrade Database. https:// comtrade.un.org (accessed 10 January 2022). 
United States, Office of the U.S. Trade Representative, Executive Office of the President (2020) Agreement between the United States of America, the United Mexican States, and Canada (USMCA). 7 January 2020, Text. https://ustr.gov/trade-agreements/free-trade-agreements/united-states-mexico-canada-agreement/ agree ment-between (accessed 14 January 2021).

United States Patent and Trademark Office (USPTO) (2020) Patent Assignment Search. https://assignment. uspto.gov/patent/index.html\#/patent/search (accessed 9 August 2020).

Velasco, L., C. Zlolniski and M.-L. Coubes (2014) De jornaleros a colonos: residencia, trabajo e identidad en el valle de San Quintín. Tijuana, Mexico: El Colegio de la Frontera Norte.

Walmart Inc. (2021) Annual Reports 1980-2021. https://stock.walmart.com/investors/fincial-information/ annual-reports-and-proxies/default.aspx (accessed 14 April 2021).

Weisbrot, M., S. Lefebvre and J. Sammut (2014) Did NAFTA Help Mexico? An Assessment after 20 Years. Center for Economic and Policy Research. http://cepr.net/documents/nafta-20-years-2014-02.pdf (accessed 9 November 2020).

Wells, M.J. (1996) Strawberry Fields. Ithaca, NY, and London: Cornell University Press.

Wolf, E. (1990) Distinguished Lecture: Facing Power - Old Insights, New Questions. American Anthropologist, 92(3) 586-596.

Wood, A.J. (2015) Networks of Injustice and Worker Mobilisation at Walmart. Industrial Relations Journal, 46(4): 259-274.

Wright, E.O. (2000) Working-class Power, Capitalist-class Interests, and Class Compromise. American Journal of Sociology, 105(4): 957-1002.

Zlolniski, C. (2010) Economic Globalization and Changing Capital-Labour Relations in Baja California. In The Antbropology of Labour Unions, edited by E. Paul Durrenberger and Karaleah S. Reichart. Boulder, CO: University of Colorado Press.

Zlolniski, C. (2019) Made in Baja: The Lives of Farmworkers and Growers behind Mexico's Transnational Agricultural Boom. Oakland, CA: University of California Press.

\section{ACKNOWLEDGEMENTS}

Research was made possible with the financial support of the Industrial and Labor Relations School at Cornell University International Programs and Graduate Office. The author benefitted from participant feedback to a prior version presented to the Labor and Employment Relations Association $72^{\text {nd }}$ Annual Meeting and the $10^{\text {th }}$ International Labor and Employment Relations Association Regional Congress for the Americas.

\section{BIOGRAPHICAL NOTE}

MATTHEW FISCHER-DALY achieved his PhD at the School of Industrial and Labor Relations at Cornell University. He holds a Master's Degree in International Economic Relations from American University, and previously advocated for international labour standards. His international and comparative research focuses on sources and uses of power by capital, states and labour in commodity networks. [Email: mmf242@,cornell.edu] 